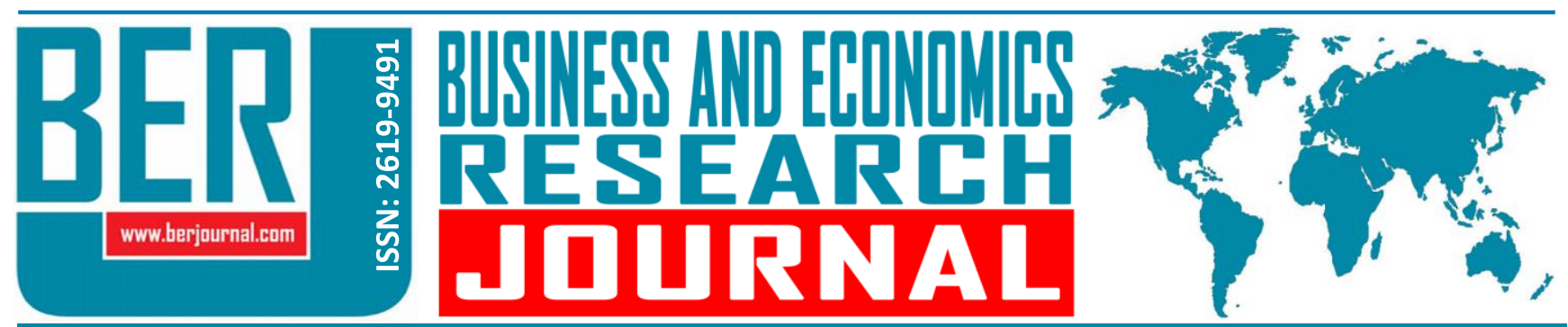

Business and Economics Research Journal Vol. 10, No. 5, 2019, pp. 1143-1153 doi: 10.20409/berj.2019.226

\title{
Corporate Reputation and Business Outcomes in Turkey ${ }^{1}$
}

\author{
Ozlem Sayilir ${ }^{\mathrm{a}}$, Telford Carl Victor ${ }^{\mathrm{b}}$
}

Abstract: The main purpose of this study is to examine how corporate reputation dimensions - management, quality, working brand, corporate social responsibility, emotional commitment, and recognition - correlate with business outcomes. The study utilizes the dataset of "2012 Corporate Reputation Research" conducted by the Reputation Research Center of Turkey (RepMan). The research comprises seven corporate reputation dimensions, five business outcome indicators, and eleven sectors in Turkey. The findings of regression analysis ascertain a strong positive relation between corporate reputation dimensions and business outcome indicators. One can say companies should attempt to improve related reputation components to enhance performance in business outcomes. According to our results, people would like to recommend a company's product or service if the companies are good in product/service quality. They would like to recommend the company as a work place even for their children if company has good emotional commitment and product and service quality. They will buy long-term stock because of good corporate social responsibility, emotional commitment, and financial strength. Material and moral support for social responsibility projects of a company depend on corporate social responsibility, emotional commitment, financial strength, and quality of management.

\author{
Keywords: Corporate \\ Reputation, Business \\ Outcomes, Reputation \\ Research, Turkey, Regression \\ Analysis
}

JEL: M10, M14

\section{Introduction}

A good reputation is a valuable asset that lets a firm to accomplish stable profitability or sustained superior financial performance. An increasing body of research claims that good corporate reputations have tactical value for the firms that own them (Roberts \& Dowling, 2002). According to Walker (2010), a good reputation can lead to numerous planned assistances such as letdown firm costs; allowing firms to charge premium prices; attracting applicants, investors, and customers; swelling profitability and making competitive barriers. The importance of reputation is becoming increasingly vital in progressively competitive markets (Abimbola \& Vallaster, 2007).

Keeping this in mind, we must be precise about how we define reputation, the features that contribute to its progress, and how it influences current and future financial performance. As defined by Fombrun (1996: 72), reputation is a perceptual representation of a company's past actions and future prospects that describe the firm's overall appeal to all its key constituents when compared to other leading

a Asst. Prof., PhD., Anadolu University, Faculty of Business Administration, Eskisehir, Turkiye, osayilir@anadolu.edu.tr (ORCID ID: 0000-0001-9598-3545)

b Master Student, Anadolu University, Social Sciences Institute, Eskisehir, Turkiye, TelfordVictor@gmail.com (ORCID ID: 00000003-2924-1433) 
rivals. This definition advises that corporate reputation is a general organizational attribute that reflects the extent to which external stakeholders see the firm as "good" and not "bad".

Generally, reputation is determined by the worth (quality) of the actor's preceding efforts (Podolny \& Phillips, 1996: 455). In several cases, the firm's outside communities may identify these efforts. As such, managers involve in explicit reputation-building activities (e.g., advertising, sponsorships) in order to expand their firms' reputations (Fombrun, 1996). They also arrange the set of links that form with exchange partners to ensure that they benefit from the network transmission of organizational reputation or status (Podolny, 1994). However, external constituencies do not directly perceive the full range of actions that lead them to form the impressions that encompass an overall reputation. They may therefore rely on previous financial performance outcomes as signals of a firm's overall esteem. This is the organizational variant of Cornell and Shapiro's (1983) product-level analysis. Just as previous demonstrations of quality lead to a reputation for product quality, previous demonstrations of overall financial performance lead stakeholders to believe that a company is 'good.'

A significant part of the present work on reputation has concentrated on building up that reputation is an important intangible resource by demonstrating its impacts on corporate financial performance (Rindova, Williamson, \& Petkova, 2010). More reputable firms can ask for a premium, which will in turn fascinate investors. A positive reputation will attract workforces and create lower employee turnover, develop client attitudes, lower a customer's perceived risk, increase the tendency to joint venture and create higher credibility. Thus, reputation is a possible source of competitive advantage (Davies, Chun, \& Kamins, 2010).

Capital Magazine, as a standout amongst the most generally known month-to-month magazines in Turkey, publishes reputation rankings of Turkish companies relying upon top managers' perceptions since 2000. Investigations of the relationship between corporate reputation and financial performance are generally rare in spite of the fact that in recent years several studies investigate this relationship. However, in Turkey, there is a gap in such investigations on the relationship between corporate reputation and business outcomes. The main objective of this study is to examine how management, quality, working brand, corporate responsibility, emotional commitment, and recognition dimensions of corporate reputation are correlated with business outcomes. This study is one of the first empirical studies in Turkey, which explores how corporate reputation is reflected on different business outcomes by utilizing a large scale field survey data about the perceptions of customers and opinion leaders. Relating corporate reputation with specific business outcomes may guide managers to focus their efforts on related corporate reputation dimensions to help improve their business outcomes.

\section{Literature Review}

Most of the studies that have considered the existence of a relationship between reputation and business outcomes have assumed the existence of a positive relationship. This method largely reflects a wideranging, streamlining assumption about how reputation influences upon future performance (Roberts \& Dowling, 1997), that is, a statement that a good reputation always positively influences financial performance. To elaborate on this slightly, it proposes that there is little or no fluctuation in the level of influence reputation has, and that this level of influence occurs at all points in time irrespective of the general economic, industrial or competitive environments. On the other hand, a more conservative or realistic view can be proposed - that the effects of reputation on business outcomes differ as a result of changes in the conditions confronting individual firms, industry sectors or the economy in general. For example, during a general economic downturn such as that brought on by the global financial crisis, even firms that had been identified as having a superior reputation were negatively affected, apparently receiving little in the way of benefit from their reputation. This suggests that if conditions are sufficiently difficult that all firms suffer, we may observe no relationship. Yet, if observed over a longer period we might find that firms with stronger reputations recover or rebound earlier or more quickly than those without. On the other hand, conditions at other points in time may be so munificent (McArthur \& Nystrom, 1991). 
In practical terms, this assumption is reflected in empirical research by the use of relatively short time periods and/or cross-sectional methodologies. Both McGuire, Pizzuto, and Getz (1990) and Nanda, Schneeweis and Eneroth (1996) relied on measures of corporate reputation in only two years, 1983 and 1989, respectively, and calculated future business outcomes using an average of only three years (1982-1984 and 1989-1991, respectively).

An alternative approach to understanding the relation between reputation and performance, however, is to focus on the capacity of firms with a superior reputation to better sustain superior profitability over an extended period of time, compared to firms without such standing. A few authors have identified that firms with superior reputations, albeit along different dimensions, were both able to sustain superior profitability over the long term and recover from positions of inferior performance faster than those without superior reputation (Roberts \& Dowling, 1997; Roberts \& Dowling, 2002). This suggests that reputation influences performance in a less direct manner and that this influence can be observed by examining the capacity of firms to sustain above average profitability for extended periods.

Roberts and Dowling (2002) who explored the existence of a relationship between firms with a superior reputation and their ability to sustain superior levels of profitability, compared to those without a superior reputation, over an extended 15-year period using a large multi-industry dataset $(3,141$ firm observations). They defined persistent profitability as a measure of "how fast abnormal profits converge upon normal long-run profit levels" (Roberts \& Dowling, 2002: 1079). The results provide strong support for the argument that firms with superior reputation tend to sustain superior levels of performance over time, compared to firms without such standing. Additionally, Roberts \& Dowling (2002) found that firms with a superior reputation were able to recover from inferior levels of performance. Nevertheless, while the use of sustained business outcomes may present a better alternative to traditional approaches of measuring reputational benefit, the mechanism through which corporate reputation influences sustained above average business outcomes remains unclear.

Both financial and management research has supported the use of corporate reputation in assessing a firm's financial performance and business outcomes. Firms perceived as excellent along an array of dimensions may have easier access to financial capital or have a lower cost of conducting their businesses. Managerial capacity is of prime interest when evaluating security selection (Harris, et al., 1975). A firm's corporate reputation quality may affect its ability to deal in cheaper implicit contracts (e.g., non-union employees) in contrast to costlier explicit contracts (Cornell \& Shapiro, 1987). As in financial theory, corporate strategic management has also emphasized the importance of measuring public perceptions of firm quality. A firm's strategic management has often been defined as the process through which a firm ensures its long-term survival. Management literature (Prahalad \& Hamel, 1994; Sanchez \& Heene, 1997) which deals with the importance of "core" areas in firms' performance is consistent with perceived quality of various firm activities being taken as a signal of imminent financial performance.

More directly, finance literature has linked management reputation and firms' equity and accounting performance. Previous researches have analyzed the relation between market and accounting based measures of U.S. firms' performance and external evaluators' perceptions of the qualitative attributes of U.S. firms (Clayman, 1987; McGuire et al., 1990; Solt \& Statman, 1989; Shefrin \& Statman, 1995). For instance, Shefrin and Statman (1995) argue that "uninformed" noise traders may tend to identify good companies' stocks as good stocks. They hypothesize that neglected or loser firms (Arbel \& Strebal, 1983) are, in fact, perceived by investors as poor in quality. These disregarded, and therefore related low-quality firms may have higher hazard balanced returns and are for the most part smaller in size. Conversely, firms apparent as great are by and large extensive and have the low book to market ratios. Utilizing expert studies on U.S. firms and British firms on corporate reputation of U.S. and British firms' over a variety of subjective components (e.g., quality of management, capacity to innovate) different authors have tended to how much perceived qualitative performance is related to a firm's subsequent accounting and equity market performance, past accounting and equity market performance forecasts future perceptions as to qualitative performance, and the interrelationships between the different qualitative factors. 
Previous studies (McGuire et al., 1990; McGuire, Sundgren, \& Schneeweis, 1988) showed that for both the U.S. and Britain, past accounting-based performance is exceedingly related to evaluators' observation of various qualitative measures (e.g., financial soundness). For most studies (Shefrin \& Statman, 1995; McGuire et al., 1988, 1990), little correlation, however, is found for either U.S. or U.K. firms, between perceived management quality and future excess risk adjusted security returns. Other studies, however, (Antunovich \& Laster, 1999) have claimed that for U.S. firms, Fortune reputation rankings are directly related to future firm equity performance.

Thus, hypothetical and empirical evidence exists on the peripheral perception of firm performance across a wide variety of qualitative characteristics as suggestive of the ability of firms to lower costs of capital, to lesser various contracting costs, to upsurge investor interest, and to accomplish higher future business outcomes. Current rankings, however, may also be related to previous financial performance. For instance, academic scholars (Smircich \& Stubbart, 1985) have said that managers and planners may be encouraged to manipulate financial data to enhance the external perception of managerial quality and strong financial performance. However, current rankings may not necessarily be related to future equity market performance. Finance theory generally admits the position that corporate equity prices includes all past information such that unless published reputation ranking contain new information that influence firms' expected risk and return, published reputation rankings should not affect future equity risk-adjusted returns.

McGuire et al. (1990) observe the relation between firm quality and business outcomes by using data from Fortune Magazine's survey of corporate reputation. They examine mainly two issues: (1) the degree to which perceived firm or management quality influences the subsequent corporate financial performance, and (2) the degree to which historical measures of corporate business outcomes forecast future perceptions of corporate or management quality. They find that financial measures of both risk and return influences perceptions of firm quality. They also obtain that perceptions of firm quality though correlated with the subsequent performance of precise financial measures, are generally more meticulously related to prior business outcomes than to succeeding performance.

Herremans, Akathaporn, and McInnes, (1993) studied whether large US manufacturing companies with better reputations for social responsibility outperform companies with poorer reputation during the sixyear period. Within the scope of this study, there are 21 manufacturing industries involved in the Fortune corporate reputation survey for the period 1982 and 1987. The results are constant with the hypothesis that companies' reputations for corporate social responsibility and their performance, as reflected by accounting measures of profitability, are predictable to be positively associated.

Hammond and Slocum (1996) examine the impact of prior firm business outcomes on subsequent corporate reputation. They obtain that business outcomes measures of market return of the firm and return on sales moderately affects the subsequent corporate reputation by using Fortune the Most Admired Companies list for the period 1981 and 1993.

Dunbar and Schwalbach (2000) inspect the relationship between corporate reputation and business outcomes of 63 German firms over the period 1988 and 1998. They find that prior business outcomes have a strong effect on subsequent reputation. Many German firms have comparatively stable reputations. Because of the study, a corporate reputation is positively related to overall business outcomes in Germany. Business outcomes have both an immediate and a year-delayed impact on corporate reputation of German firms.

Roberts and Dowling (2002) consider the relationship between corporate reputation and superior financial performance and business outcomes. Their data sample is grounded on a sample from 1984-1998 of Fortune's report of America's Most Admired Corporations. This paper observes whether a good reputation allows a firm to achieve insistent profitability or sustained superior financial performance. They put yearly observations on firm profitability, market-to-book value and firm size for each firm. They find that firms with superior corporate reputations have a greater chance of sustaining superior business outcomes over time. 
According to Sabate and Puente (2003), the affiliation between corporate reputation and business outcomes comprises answering two questions; whether the relationship sign as positive or negative and whether corporate reputation has an impact on business outcomes or vice versa. They noted that for developed countries the positive influence of corporate reputation on business outcomes has always been validated, despite studies' using various methodologies and using data of heterogeneous nature, both for measures of corporate reputation, of financial performance, and of using several different lags.

Rose and Thomsen (2004) examine the relationship between a firm's reputation and business outcomes on Danish firms for the period 1996 and 2001. They find that corporate reputation does not impact firm value (the market-to-book value of equity) whereas corporate business outcomes progresses corporate reputation.

Eberl and Schwaiger (2005) analyze the relationship between corporate reputation and the firm's future business outcomes by means of a more differentiated concept of reputation than the one commonly used in literature by using German firms' data. They obtain two important conclusions. Firstly, superior business outcomes in the past is only one component of a company's reputation. Secondly, reputation's "cognitive component" has a positive impact on future business outcomes while there is strong evidence that the "emotional component" has a negative impact.

Inglis, Morley and Sammut (2006) test the relationship between corporate reputation and business outcomes by using Australian data for the period 2003 and 2004. Following Rose and Thomsen's (2004) methodology (ROA, ROE and ROIC), they find no causal relationship between corporate reputation and business outcomes in either direction for Australian firms in sample period.

Sanchez and Sotorrio (2007) empirically test the relationship between corporate reputation and business outcomes of the 100 most prestigious companies operating in Spain in 2004. They find that there exists a strong and nonlinear relationship between business reputation and the financial result of the company.

Zhang and Rezaee (2009) examine the relationship between corporate credibility and business outcomes in China. In their research, they used both accounting-based and stock market-based analysis. Net profit margin, ROE, and sales growth rates are the accounting-based business outcomes measures; marketadjusted return and total returns are stock market-based firm business outcomes measures. In addition, they also considered other business outcomes measures for instance assets, capital, and growth of profit before tax, ROA, and cost of capital. They acquire that firms with high credibility have more low cost implied claims than other firms, thus exhibiting higher financial performance.

\section{Data and Methodology}

Corporate Reputation Researches started with the "RepMan Study" in Turkey. Reputation Research Center of Turkey (RepMan) is a knowledge sharing center which is a basic source and model of reputation researches in Turkey. Its mission is to accumulate information about reputation researches and later share to both academicians and practitioners. The data which has been used in the study was taken from the dataset of "2012 Corporate Reputation Research" conducted by the Reputation Research Center of Turkey (RepMan Study) where 7 geographical regions, 15 cities with 14,176 participants including 929 opinion leaders were in the participation list. All of them provide very essential data to the company executives to decide on their strategic preferences on reputation. The RepMan Reputation Score (RMS) was calculated by measuring the performances of the companies of different sectors on recognition, management quality, product and services quality, working brand, financial stability, corporate (social) responsibility and emotional attachment aspects.

The study utilizes the dataset of "2012 Corporate Reputation Research", which was conducted by the Reputation Research Center of Turkey (RepMan). The data consists of seven corporate reputation components (dimensions of reputation) which are used to compute a composite reputation score called RMS (by factor analysis). These components are as follows: 
- Corporate Responsibility (CSR),

- Emotional Commitment (EC),

- Financial Strength (FS),

- Product/Service Quality (PSQ),

- Quality of Management (QM),

- Working Brand (WB),

- Recognition (RC).

Moreover, it includes five business outcomes indicators:

- RR: In every aspect, I express that this company is reputable and reliable,

- RPS: I would like to use / re-use / recommend this company's products / services,

- RPW: It is a company that I would recommend as a place to work / work for my child / myself,

- BLS: I am interested to buy stocks for long-term,

- SSRP: I have material and moral support for social responsibility projects.

The companies or brands investigated comprises eleven sectors*:

- Automotive,

- Banking,

- Construction,

- Durable consumption,

- Fast moving consumption,

- Holding,

- Liquid fuel,

- $\quad$ LPG gas,

- Retail

- Telecommunication,

- Transportation

The study scrutinizes the impact of corporate reputation on business outcomes indicators. Here, OLS regression method considers business outcomes indicators as a dependent variable and other variablesCorporate Responsibility (CR), Emotional Commitment (EC), Financial Strength (FS), Product/Service Quality (PSQ), Quality of Management (QM), Working Brand (WB), and Recognition (RC)-as independent or explanatory variables.

\section{Findings}

We present the descriptive statistics of business outcomes and the descriptive statistics of corporate reputation indicators Table 1 and Table 2 . 
O. Sayilir - T. C. Victor

Table 1. Descriptive Statistics of Business Outcomes

\begin{tabular}{|l|c|c|c|c|c|}
\hline Variables & RR & RPS & RPW & BLS & SSRP \\
\hline N & 101 & 154 & 154 & 154 & 154 \\
\hline Mean & 60.7156 & 59.9942 & 59.0691 & 50.5502 & 58.0415 \\
\hline Median & 60.0300 & 59.2500 & 58.0850 & 50.4550 & 57.1100 \\
\hline Mode & $56.54^{\mathrm{a}}$ & 59.16 & $52.55^{\mathrm{a}}$ & $41.95^{\mathrm{a}}$ & $56.82^{\mathrm{a}}$ \\
\hline Std. Dev. & 7.66327 & 7.16923 & 6.91200 & 6.19039 & 6.43195 \\
\hline Skewness & 0.171 & 0.271 & 0.254 & 0.095 & 0.386 \\
\hline Kurtosis & 0.426 & 0.248 & -0.013 & 0.499 & -0.077 \\
\hline Minimum & 40.90 & 39.74 & 39.63 & 33.48 & 43.95 \\
\hline Maximum & 82.59 & 80.66 & 78.32 & 69.70 & 75.41 \\
\hline
\end{tabular}

a. Multiple modes exist. The smallest value is shown

Table 2. Descriptive Statistics of Corporate Reputation Indicators

\begin{tabular}{|l|c|c|c|c|c|c|c|}
\hline Variables & QM & PSQ & WB & FS & CSR & EC & RC \\
\hline $\mathbf{N}$ & 154 & 154 & 154 & 154 & 154 & 154 & 154 \\
\hline Mean & 62.2136 & 61.5877 & 61.4247 & 62.6227 & 57.7974 & 57.8727 & 43.8396 \\
\hline Median & 61.7000 & 60.9000 & 61.1000 & 61.8500 & 57.2500 & 57.0000 & 46.3000 \\
\hline Mode & 58.50 & $57.60^{\mathrm{a}}$ & 61.40 & $55.40^{\mathrm{a}}$ & 57.00 & $51.60^{\mathrm{a}}$ & 15.40 \\
\hline Std. Dev. & 6.79108 & 6.72792 & 6.69654 & 6.49489 & 6.08869 & 6.87010 & 22.6361 \\
\hline Skewness & 0.360 & 0.383 & 0.369 & 0.493 & 0.511 & 0.498 & -0.146 \\
\hline Kurtosis & 0.461 & 0.416 & 0.252 & 0.001 & 0.616 & 0.279 & -1.244 \\
\hline Minimum & 44.10 & 42.40 & 44.40 & 49.80 & 44.10 & 41.40 & 1.80 \\
\hline Maximum & 83.70 & 81.60 & 81.70 & 82.00 & 78.60 & 78.30 & 84.70 \\
\hline
\end{tabular}

a. Multiple modes exist. The smallest value is shown

We examine the impact of corporate reputation dimensions on business outcomes - RR, RPS, RPW, BLS, and SSRP by regression analysis. RMS components of corporate social responsibility, emotional commitment, financial strength, product/service quality, quality of management, recognition and working brand on the business outcomes of RR, RPS, RPW, BLS and SSRP.

Table 3. Coefficients of Regression Models

\begin{tabular}{|l|c|c|c|c|c|}
\hline $\begin{array}{l}\text { Independent / } \\
\text { Dependent } \\
\text { Variables }\end{array}$ & RR & RPS & RPW & BLS & SSRP \\
\hline CSR & $0.58^{* *}$ & & & $0.73^{* * *}$ & $-0.25^{*}$ \\
\hline EC & & & $0.37^{*}$ & $0.68^{* * *}$ & $0.92^{* * *}$ \\
\hline FS & & & & $-0.66^{* *}$ & $0.62^{* * *}$ \\
\hline PSQ & & $0.41^{* *}$ & $0.70^{* *}$ & & \\
\hline QM & $0.04^{*}$ & & & & $-0.36^{*}$ \\
\hline RC & & & & & \\
\hline WB & 0.89 & 0.89 & 0.85 & 0.77 & 0.89 \\
\hline Adjusted R & $118.97^{* * *}$ & $180.88^{* * *}$ & $128.86^{* * *}$ & $74.43^{* * *}$ & $171.92^{* * *}$ \\
\hline F-statistic & \multicolumn{7}{|l}{} \\
\hline *p $<0.05,{ }^{* *} \mathrm{p}<0.01,{ }^{* * *} \mathrm{p}<0.001$ & & & \\
\hline
\end{tabular}

When we regress RMS components of corporate social responsibility, emotional commitment, financial strength, product/service quality, quality of management, recognition and working brand on the business outcome of RR (In every aspect, I express that this company is reputable and reliable), the model 
estimated seems to be statistically significant. The RMS components which are statistically significant in the regression model are corporate social responsibility. As expected, the respondents tend to support businesses, which have a significant participation in corporate social responsibilities and have a good recognition. This finding reflects the satisfaction of respondents to the businesses with a recognizable corporate social responsibility and good recognition.

When we regress RMS components of corporate social responsibility, emotional commitment, financial strength, product/service quality, quality of management, recognition and working brand on the business outcome of RPS (I would like to use / re-use / recommend this company's products / services), the model estimated seems to be statistically significant. The only one RMS component, which is significant in the regression model, is product/service quality. This component, product/service quality, has a positive relationship with RPS. As expected, the respondents tend to provide more support for the business which are good in product/service quality, in other word, good product/service quality motivate the respondents to recognize reputable businesses. This finding reflects the satisfaction of respondents to the businesses with a superior product/service quality.

When we regress RMS components of corporate social responsibility, emotional commitment, financial strength, product/service quality, quality of management, recognition and working brand on the business outcome of RPW (It is a company that I would recommend as a place to work / work for my child / myself), the model estimated seems to be statistically significant The RMS components which are significant in the regression model are emotional commitment and product/service quality $(\beta=.56, p<.01)$. These components each have a positive relationship with RPW. As expected, the respondents tend to provide more support for the business, which are good in emotional commitment, and product/service quality, in other words, robust emotional commitment and good product/service quality motivate the respondents to recognize reputable businesses. This finding reflects the satisfaction of respondents to the businesses with a strong emotional commitment and good product/service quality.

When we regress RMS components of corporate social responsibility, emotional commitment, financial strength, product/service quality, quality of management, recognition and working brand on the business outcome of BLS (I am interested to buy stocks for long-term), the model estimated seems to be statistically significant. The RMS components, which are significant in the regression model, are corporate social responsibility, emotional commitment and financial strength. There is a positive relationship between BLS and corporate social responsibility and emotional commitment. As expected, the respondents tend to support businesses, which are good in emotional commitment and corporate social responsibilities. However, they tend to provide less support to the businesses, which are less reputable in terms of financial strength. This finding may reflect the desire of respondents to enhance the reputation of businesses with an inferior FS by supporting their financial strength activities.

We regress RMS components of corporate social responsibility, emotional commitment, financial strength, product/service quality, quality of management, recognition and working brand on the business outcome of SSRP (I have material and moral support for social responsibility projects), the model estimated seems to be statistically significant. The RMS components, which are significant in the regression model, are emotional commitment, financial strength, corporate social responsibility, and quality of management. There is a positive relationship between SSRP and emotional commitment and financial strength. As expected, the respondents tend to support CSR activities of businesses to which they feel emotionally attached and of businesses, which they perceive as financially strong. However, they tend to provide support to the CSR activities of businesses perceived as less reputable in terms of corporate social responsibility and quality of management. This finding may reflect the desire of respondents to enhance the reputation of businesses with an inferior CSR performance and quality of management by supporting their CSR and management activities. 


\section{Conclusion}

There are numerous studies, which have examined and discussed the relationship between corporate reputation and business outcomes of a company. Interestingly, most of studies have considered the existence of a relationship between reputation and business outcomes. This method largely reflects a wide-ranging, streamlining assumption about how reputation affects upon future performance (Roberts \& Dowling, 1997), that is, a statement that a good reputation always positively influences business outcomes. Remarkably, the findings of the study are in line with Roberts and Dowling's streamlining assumptions: a positive correlation between corporate reputation indicators and business outcomes as well as significant influence of corporate reputation indicators on business outcomes.

The prime objective of this research is to examine the correlation between corporate reputation and business outcomes as well as the influence of corporate reputation on business outcomes. Alongside, the study has also promptly answered the research questions addressing two major findings: i) reputational dimensions (management, quality, working brand, corporate responsibility, emotional commitment, and recognition) significantly correlated to business outcomes, and ii) corporate reputation indicators have significant influence on business outcomes. It is noticeable, considering the hypothesis, that all the five regression models lead us to reject null hypothesis ( $\mathrm{Ho}$ ) implying that corporate reputation score and its various components (dimensions) do have impact on different business outcome indicators.

In summary, attaining positive business outcomes is highly likely essential for a company to maximize the profit or wealth and survive in the competitive market. Now, regarding the findings of regression analysis, the research has concluded that if any company wants to ensure the robustness of business outcomes, in other words, their customers' positive perceptions, then, of course, they should intensely concentrate on and work for boosting the value of the corporate reputation dimensions. Concentrating more on the corporate reputation indicators may provide them more confidence and chance of surviving in the competitive market.

One can say companies should attempt to improve related reputation components to enhance performance in business outcomes. According to our results, for instance, people would like to recommend a company's product or service if the companies are good in product/service quality. They would like to recommend the company as a work place even for their children if company has good emotional commitment and product and service quality. They will buy long-term stock because of good corporate social responsibility, emotional commitment, and financial strength. Material and moral support for social responsibility projects of a company depend on corporate social responsibility, emotional commitment, financial strength, and quality of management.

The data which has been used in the study was taken from the dataset of " 2012 Corporate Reputation Research" conducted by the Reputation Research Center of Turkey (RepMan) where 7 geographical regions, 15 cities with 14,176 participants including 929 opinion leaders were in the participation list. The main purpose is to find the influence of the corporate reputation over the business outcomes and the research has used five indicators to analyze the business outcomes as well as eleven sectors as the sample. As reputation is an intangible asset and cannot be accomplished over-night, data of longer period or continuous survey could have been more accurate for the study. automotive, banking, construction, durable consumption, fast-moving consumption, holding, liquid fuel, LPG gas, retail, telecommunication, and transportation sectors' data have been employed in the analysis. Thus, the study may not be precisely accurate for other sectors in Turkey. As the investigation on the relationship between corporate reputation and business outcomes is relatively new in Turkey and more studies need to be conducted on this field.

\section{End Notes}

1. This research article is extracted from the Master Thesis of Telford Carl VICTOR (Supervisor: Özlem SAYILIR) entitled CORPORATE REPUTATION AND BUSINESS OUTCOMES IN TURKEY, 2018 (Anadolu University, Social Sciences Institute). 


\section{References}

Abimbola, T., \& Vallaster C. (2007). Brand, organisational identity and reputation in SMEs: An overview. Qualitative Market Research: An International Journal, 10(4), 341-348.

Arbel, A., \& Strebel, P. (1983). Pay attention to neglected firms! The Journal of Portfolio Management, 9(2), 37-42.

Antunovich, P., \& Laster, D. (1999). Do investors mistake a good company for a good investment? February 1999, SSRN Electronic Journal, DOI: 10.2139/ssrn.115020.

Cornell, B., \& Shapiro, A. C. (1987). Corporate stakeholders and corporate finance. Financial Management, 16(1), 5-14.

Clayman, M. (1987). In search of excellence: The investor's viewpoint. Financial Analysts Journal, 43(3), 54-63.

Davies, G., Chun, R., \& Kamins, M. A. (2010). Reputation gaps and the performance of service organizations. Strategic Management Journal, 31(5), 530-546.

Dunbar, R. L., \& Schwalbach, J. (2000). Corporate reputation and performance in Germany. Corporate Reputation Review, 3(2), 115-123.

Eberl, M., \& Schwaiger, M. (2005). Corporate reputation: Disentangling the effects on financial performance. European Journal of Marketing, 39(7/8), 838-854.

Fombrun, C. (1996). Reputation. John Wiley \& Sons, Ltd.

Harris, R. K., Drakenberg, T., \& Wennerström, H. (1975). Bandshape phenomena in liquids. In Nuclear Magnetic Resonance (pp. 141-173).

Herremans, I. M., Akathaporn, P., \& Mclnnes, M. (1993). An investigation of corporate social responsibility reputation and economic performance. Accounting, Organizations and Society, 18(7-8), 587-604.

Hammond, S. A., \& Slocum, J. W. (1996). The impact of prior firm financial performance on subsequent corporate reputation. Journal of Business Ethics, 15(2), 159-165.

Inglis, R., Morley, C., \& Sammut, P. (2006). Corporate reputation and organisational performance: An Australian study. Managerial Auditing Journal, 21(9), 934-947.

McArthur, A. W., \& Nystrom, P. C. (1991). Environmental dynamism, complexity, and munificence as moderators of strategy-performance relationships. Journal of Business Research, 23(4), 349-361.

McGuire, J. B., Sundgren, A., \& Schneeweis, T. (1988). Corporate social responsibility and firm financial performance. Academy of Management Journal, 31(4), 854-872.

McGuire, B., Pizzuto, T., \& Getz, L. L. (1990). Patterns of visitation in prairie voles (Microtus ochrogaster) reveal a role for males in population regulation. In Social systems and population cycles in voles (pp. 98-99). Birkhäuser, Basel.

Nanda, S., Schneeweis, T., \& Eneroth, K. (1996). Corporate performance and firm perception: The British experience. European Financial Management, 2(2), 197-221.

Podolny, J. M. (1994). Market uncertainty and the social character of economic exchange. Administrative Science Quarterly, 39(3), 458-483.

Podolny, J. M., \& Phillips, D. J. (1996). The dynamics of organizational status. Industrial and Corporate Change, 5(2), 453471.

Prahalad, C. K., \& Hamel, G. (1994). Strategy as a field of study: Why search for a new paradigm? Strategic Management Journal, 15(S2), 5-16.

Rindova, V. P., Williamson, I. O., \& Petkova, A. P. (2010). Reputation as an intangible asset: Reflections on theory and methods in two empirical studies of business school reputations. Journal of Management, 36(3), 610-619.

Roberts, P. W., \& Dowling, G. R. (2002). Corporate reputation and sustained superior financial performance. Strategic Management Journal, 23(12), 1077-1093.

Roberts, D. W., Walker, J., \& Dowling, T. I. (1997). FLAG: A fuzzy landscape analysis GIS method for dryland salinity assessment (pp. 121-125). CSIRO Land and Water.

Rose, C., \& Thomsen, S. (2004). The impact of corporate reputation on performance: Some Danish evidence. European Management Journal, 22(2), 201-210.

Sabate, J., \& Puente, E. (2003). Empirical analysis of the relationship between corporate reputation and financial performance: A survey of the literature. Corporate Reputation Review, 6(2), 161-177.

Sanchez, R., \& Heene, A. (1997). Competence-based strategic management: Concepts and issues for theory, research, and practice (3-42). Wiley. 
Sanchez, J. L. F., \& Sotorrío, L. L. (2007). The creation of value through corporate reputation. Journal of Business Ethics, 76(3), 335-346.

Shefrin, H., \& Statman, M. (1995). Making sense of beta, size, and book-to-market. Journal of Portfolio Management, 21(2), 26.

Schwaiger, M. (2004). Components and parameters of corporate reputation. Schmalenbach Business Review, 56(1), 4671.

Solt, M. E., \& Statman, M. (1989). Good companies, bad stocks. Journal of Portfolio Management, 15(4), 39-44.

Smircich, L., \& Stubbart, C. (1985). Strategic management in an enacted world. Academy of Management Review, 10(4), 724-736.

Walker, K. (2010). A systematic review of the corporate reputation literature: Definition, measurement, and theory. Corporate Reputation Review, 12(4), 357-387.

Zhang, R., \& Rezaee, Z. (2009). Do credible firms perform better in emerging markets? Evidence from China. Journal of Business Ethics, 90(2), 221. 
This Page Intentionally Left Blank 